\title{
In Vivo Cell Lineage Analysis During Chemical Hepatocarcinogenesis in Rats Using Retroviral-Mediated Gene Transfer: Evidence for Dedifferentiation of Mature Hepatocytes
}

\author{
Jérôme Gournay, Isabelle Auvigne, Virginie Pichard, Catherine Ligeza, \\ Marie-Pierre Bralet, and Nicolas Ferry

\begin{abstract}
Laboratoire de Thérapie Génique (JG, IA, VP, CL, NF), Hôtel-Dieu, and Unité d'Hépatologie (JG), Centre Hospitalier Universitaire de Nantes, Nantes, and Département de Pathologie (M-PB), Hôpital Henri Mondor, AP-HP, Créteil, France
\end{abstract}

SUMMARY: Feeding adult rats with a diet containing 2-acetylaminofluorene (2-AAF) results in suppression of hepatocyte proliferation and stimulation of oval cell proliferation. Although oval cells may be facultative liver stem cells, the actual relationship between oval cells and liver cancer has not been clearly established in vivo. Our goal was to label hepatic cells in vivo using retroviral vectors and follow their fate during the early steps of chemically induced hepatocarcinogenesis. Oval cell proliferation was induced by continuous feeding with a carcinogenic diet containing 2-AAF. We used two different strategies to genetically label hepatic cells: (a) labeling of proliferating cells in rats fed 2-AAF by injecting recombinant retroviral vectors containing the $\beta$-galactosidase gene either in a peripheral vein or in the common bile duct at the peak of oval cell proliferation and (b) prelabeling of hepatocytes by intravenously injecting recombinant vectors 1 day after partial hepatectomy and 1 week before subsequent administration of 2-AAF. Using the first strategy, transgene expression occurred in both oval cells and hepatocytes. Using the second strategy, we could selectively label, and hence study the fate of, differentiated hepatocytes. In the latter case, we observed clusters of $\beta$-galactosidase-positive hepatocytes, some of them also expressing preneoplastic markers such as gamma-glutamyl transpeptidase as well as the placental form of glutathione-S-transferase. These results demonstrate that preneoplastic foci can originate from mature hepatocytes and are consistent with the hypothesis that dedifferentiation of mature hepatocytes may occur during the course of carcinogenic regimen. (Lab Invest 2002, 82:781-788).

$H$ epatocellular carcinoma is a tumor with an increasing incidence worldwide. Various rodent models of chemically induced liver tumors are currently used to study molecular and cellular events during hepatocarcinogenesis. Many of these models are characterized by the proliferation of unusual epithelial cells called "oval cells" (Farber, 1956). For example, administration of 2-acetylaminofluorene (2AAF) together with partial hepatectomy results in suppression of hepatocyte proliferation and stimulation of oval cell proliferation (Solt and Farber, 1976). Oval cells arise in the periportal region of the liver probably from cells of the Hering canal (Grisham and Porta, 1964; Novikoff et al, 1991), from bile ducts (Sarraf et al, 1994), from intraportal or periportal ductules (Petersen et al, 1997), or from periductal cells (Sell and Salman, 1984). Recently, it has also been

DOI: 10.1097/01.LAB.0000017363.11489.AD

Received March 12, 2002.

Supported by grants from the Association pour la Recherche contre le Cancer, the Fondation pour la Recherche Médicale, and the Ligue départementale contre le Cancer.

Address reprint requests to: Dr. Nicolas Ferry, Laboratoire de Thérapie Génique, Hôtel Dieu, Centre Hospitalier Universitaire de Nantes, 44035 Nantes cedex 01, France. E-mail: nferry@sante.univ-nantes.fr suggested that oval cells may derive from bone marrow cells (Petersen et al, 1999). Because the appearance of oval cells is one of the earliest cellular responses to most carcinogenic regimens, it has been suggested that the oval cell population is derived from remnant liver stem cells still present in the adult liver (Petropoulos et al, 1985). This hypothesis is reinforced by the fact that oval cells are pluripotent, with the ability to differentiate into both hepatocytes (Coleman et al, 1993; Evarts et al, 1987) and bile duct cells (Lenzi et al, 1992). Thus, oval cells may be directly involved in the development of hepatocellular carcinoma by blockade of their maturation (Sell and Dunsford, 1989).

The alternate hypothesis for liver tumor genesis is based on dedifferentiation of mature hepatocytes, which may account for tumor development without the involvement of other cell types (Farber, 1984). According to this latter model, cancer results from a multistep process. Chemical carcinogens first act by modifying DNA to form DNA adducts during the first step of initiation. In the second step of carcinogenesis, often referred to as promotion, other noncarcinogenic compounds increase hepatocarcinogenic effects, most of them being able to induce cellular proliferation. Arguments for this latter hypothesis are the findings that exposure of rats to carcinogens results in 
sequential liver alterations as follows: (a) focal proliferation of altered hepatocytes, (b) appearance of preneoplastic nodules, and (c) rise of cancer from persistent nodules (Farber and Sarma, 1987).

Many studies have been performed in an attempt to validate one of these two hypotheses by analyzing the fate of different cell types in the liver during early and late stages of carcinogenesis. Such cell lineage studies used various strategies: morphologic examination (Dunsford et al, 1985; Grisham and Hartroft, 1961), use of metabolic and phenotypic markers (Dempo et al, 1975; Dunsford and Sell, 1989; Golding et al, 1995; Hixson et al, 1990; Sell, 1978; Thompson-Hayner et al, 1984), analysis of transgenic mice models (Bennoun et al, 1993; Schirmacher et al, 1991), and labeling of dividing cells with $\left[{ }^{3} \mathrm{H}\right]$ thymidine (Evarts et al, 1987; Sell and Salman, 1984). Also, cell lineage of oval cells was studied after ex vivo labeling of oval cells that were subsequently reimplanted into recipient animals (Coleman et al, 1993; Dabeva et al, 1997). Most of the studies of oval cells strengthened the hypothesis that these cells have a potential role as a "facultative stem cell" and serve as progenitors for hepatocytes, although contradictory results were also obtained by some authors (Gerlyng et al, 1994; Lenzi et al, 1992; Tatematsu et al, 1984). However, it was suggested that oval cell proliferation and development of hepatocellular tumors are independent and result from activation of a different cell lineage (Anilkumar et al, 1995; Steinberg et al, 1991; Tarsetti et al, 1993).

Genetic labeling represents an attractive method to study in vivo cell lineage. Indeed, retroviral vectors meet many requirements for cell lineage analysis (Bralet et al, 1994; Lemischka, 1993).-First, infection with recombinant retroviruses results in stable integration of the marker gene in the infected cell. Such integration leads to replication of the transgene along with the cellular genome and therefore to transmission of the label to the progeny of one single cell. Second, the expression of the marker gene is restricted to the cells that have integrated the transgene. Third, the use of a marker gene, such as the Escherichia coli $\beta$-galactosidase coupled to a nuclear localization signal (Kalderon et al, 1984), allows precise immunohistochemical or histochemical detection of the labeled cells.

In the present report, our goal was to gain further insights into the relationship between preneoplastic foci and hepatocytes in the livers of rats treated with sustained administration of 2-AAF using in vivo genetic labeling. For this purpose, we performed retroviral-mediated genetic labeling of cells in two groups of rats: in the first group, genetic labeling was performed after the introduction of the carcinogenic regimen to target cells induced to proliferate by such regimen. In the second group, genetic labeling was performed after partial hepatectomy before introduction of the carcinogenic regimen to specifically label mature hepatocytes. In both groups, animals were killed at the end of 2-AAF administration and the presence, the distribution, the type, and the level of differentiation of $\beta$-galactosidase-positive cells were determined.

\section{Results}

A first series of animals (Group 1) received 2-AAF and were subjected to a two-thirds hepatectomy at Day 7 according to the protocol described in Figure 1. As expected, we observed oval cells as early as 4 days after the two-thirds hepatectomy. The proliferation of oval cells was initially localized around the portal tract and subsequently invaded the hepatic lobule. According to previous studies, we observed that the peak of oval cell division occurred 7 days after partial hepatectomy (Evarts et al, 1987). Because retroviral vectors are only able to infect dividing cells (Hajihosseini et al, 1993; Roe et al, 1993), they were administered to the animals at that time, either via the common bile duct or via a peripheral vein to label oval cells. We analyzed the number and the type of $\beta$-galactosidase-positive cells in various sections obtained from different lobes in animals killed 1 and 2 weeks after gene transfer (ie, 3 and 4 weeks after the beginning of 2-AAF feeding). In animals injected via a peripheral vein, we observed only $\beta$-galactosidase-positive hepatocytes by 5 -bromo-4-chloro-3-indolyl- $\beta$-Dgalactopyranoside (X-Gal) staining of cryostat sections (Fig. 2A) or by immunohistochemistry (Fig. 2B). These positive hepatocytes were sometimes arranged in small clusters (up to 24 cells) in the livers of 4 of 5 animals. No $\beta$-galactosidase-positive oval cells were detected in the livers of these animals. In contrast, after delivery of
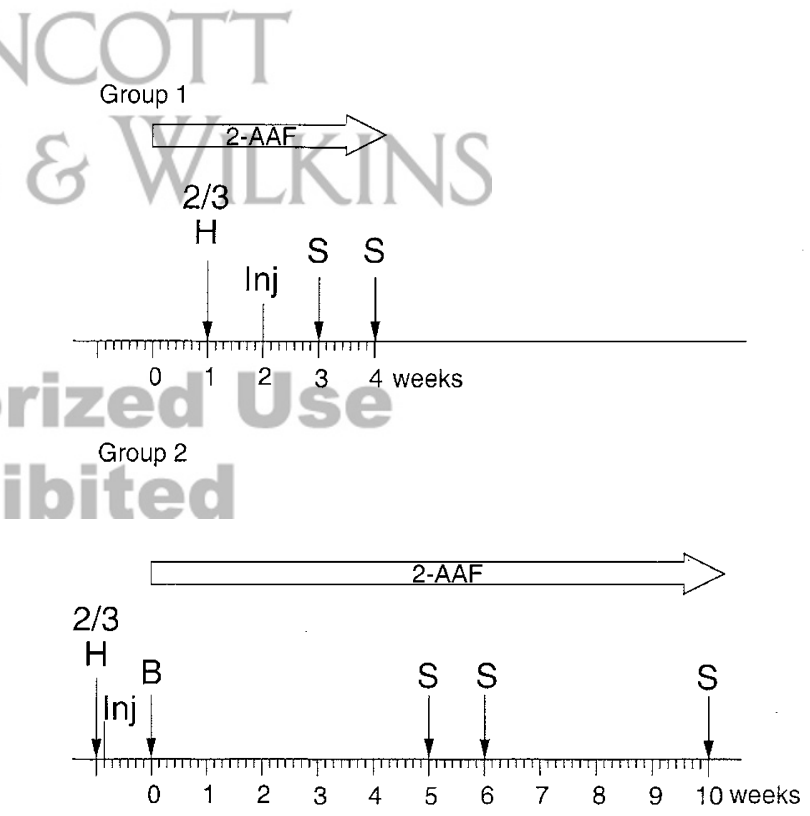

Figure 1.

Experimental procedures for the two groups of rats included in the study. In Group 1, partial hepatectomy was performed 1 week after the onset of 2-acetylaminofluorene (2-AAF) feeding. Injection of retroviral vectors (Inj) was performed either through the bile duct or intravenously 1 week after partial hepatectomy. In Group 2, animals were hepatectomized and injected intravenously with retroviral vectors 1 week before the beginning of 2-AAF administration. Cyclophosphamide was injected at the time of virus administration (see "Materials and Methods"). A liver biopsy (B) was performed 1 week after virus injection at the start of 2-AAF regimen. Inj = injection of retrovirus; $2 / 3 \mathrm{H}=$ two-thirds partial hepatectomy; $S=$ sacrifice; $B=$ liver biopsy. 

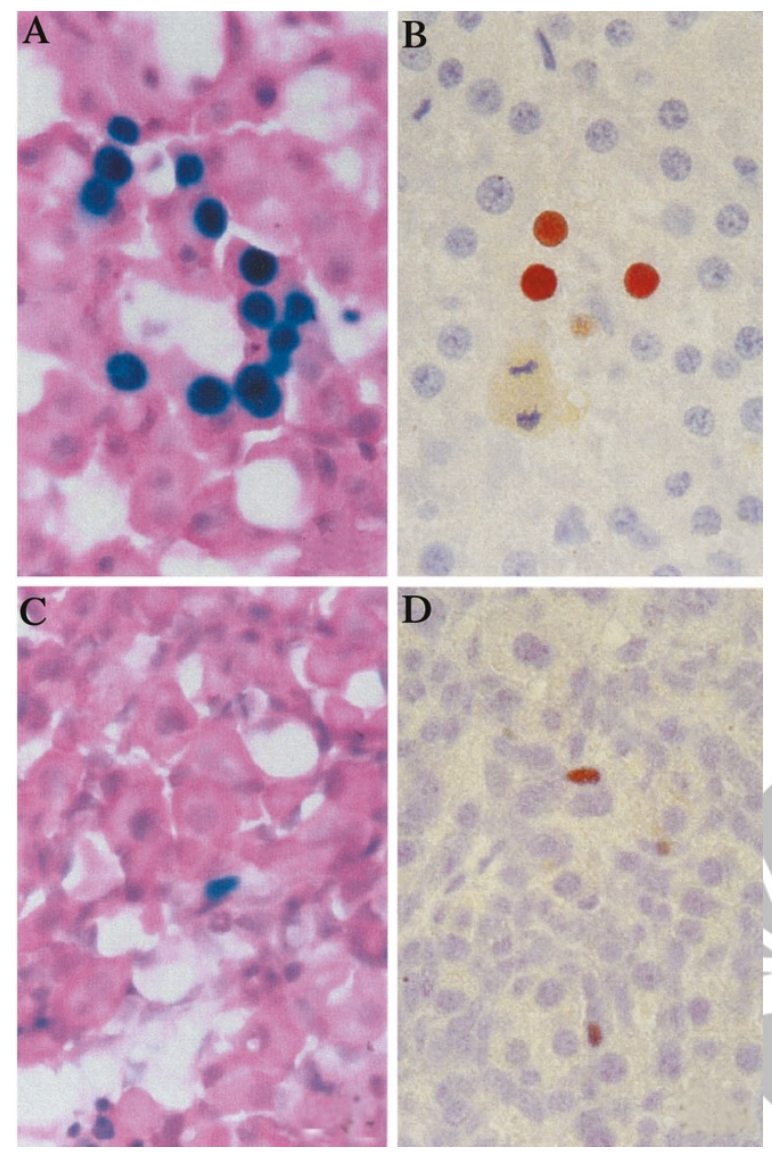

Figure 2.

Histochemical and immunohistochemical analysis of livers in Group 1 animals. Rats were fed 2-AAF and injected with retroviral vectors either via the portal vein ( $A$ and $B$ ) or the bile duct ( $C$ and $D)$. The presence of labeled cells was analyzed by 5 -bromo-4-chloro-3-indolyl- $\beta$-D-galactopyranoside staining on cryostat sections ( $A$ and $C$ ) or by immunohistochemical detection of $\beta$-galactosidase on paraffin sections ( $B$ and $D)$. Both techniques revealed the presence of labeled hepatocytes ( $A$ and $B$ ) as well as labeled oval cells ( $C$ and D). Magnification, $\times 1000$.

retroviral vectors via the common bile duct, we observed the presence of $\beta$-galactosidase-positive oval cells near the portal tract either by histochemistry (Fig. 2C) or immunohistochemistry (Fig. 2D). However, $\beta$-galactosidase-labeled hepatocytes were always present along with $\beta$-galactosidase-positive oval cells in these animals. At that time, we also observed hepatocyte mitosis, indicating that 2-AAF had not completely blocked hepatocyte regeneration and had allowed retroviral-mediated gene transfer in hepatocytes.

To specifically label one cell population, we performed prelabeling of mature hepatocytes. To this end, a second series of rats (Group 2) were submitted to a two-thirds partial hepatectomy and received $\beta$-galactosidase retroviral vectors by systemic injection 22 and 27 hours later. This protocol allows specific labeling of hepatocytes, which divide 24 hours after partial hepatectomy, whereas nonparenchymal cells divide later (Fabrikant, 1968; Grisham, 1962). Because retroviral vectors only infect dividing cells, hepatocytes are specifically labeled using this approach. Moreover, rats received cyclophosphamide
(100 mg/kg intravenously) 1 hour before the first injection of virus to decrease the immune response observed after systemic high-titer retroviral vector delivery (Izembart et al, 1999). Indeed, it has been demonstrated that this treatment allowed prolonged expression of $\beta$-galactosidase in the liver after adenoviral-mediated gene transfer (Jooss et al, 1996). Seven days after retrovirus delivery, after completion of liver regeneration, rats were fed with 2-AAF and sequential biopsy specimens were obtained to detect the presence of $\beta$-galactosidase-positive hepatocytes (Fig. 1).

One week after the injection of $\beta$-galactosidase retroviral vectors, immunohistochemical analysis of liver biopsy specimens revealed the presence of an average of $25 \% \quad \beta$-galactosidase-positive hepatocytes, indicating that mature hepatocytes had been successfully infected (Fig. 3A). This figure is in keeping with our previous studies of liver gene transfer using high-titer retroviral vectors (Kitten et al, 1997). We never detected other cell types that were positive for $\beta$-galactosidase, indicating that labeling was hepato-
A
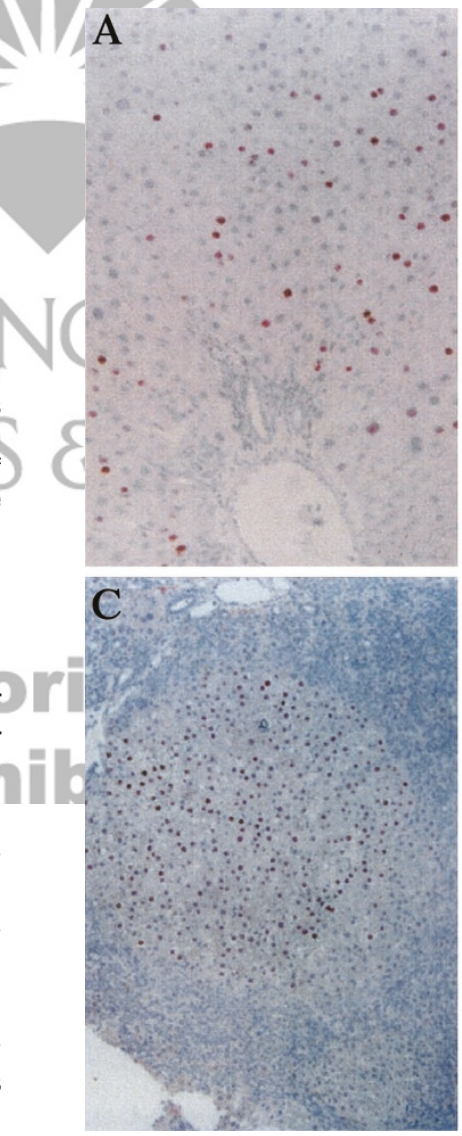
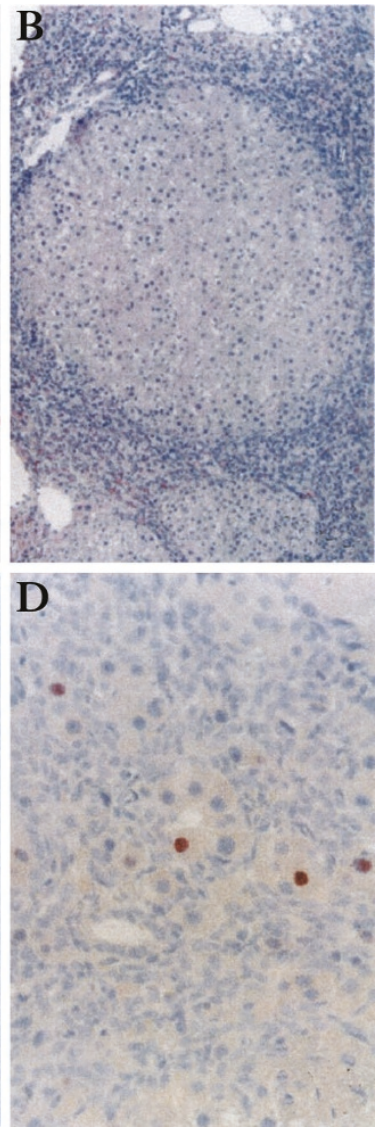

Figure 3.

Immunohistochemical analysis of liver in Group 2 rats. A, Liver biopsy specimen obtained from a prelabeled rat, before administration of 2-AAF. Many $\beta$-galactosidase-positive hepatocytes are scattered throughout the lobule. Hematoxylin counterstained. (Magnification, $\times 200$ ). B and C, Serial sections of a liver nodule within the hepatic lobule surrounded with oval cells (B). All hepatocytes in the nodule are positive for $\beta$-galactosidase (C). (Magnification, $\times 100)$. D, $\beta$-galactosidase-positive hepatocytes completely surrounded by oval cells in liver specimen obtained at the time of death, 6 weeks after the beginning of the carcinogenic regimen. (Magnification, $\times 200$ ). 
cyte specific. Rats were killed at 5, 6, and 10 weeks after the beginning of 2-AAF administration. At the time of death, we observed the presence of clusters of hepatocytes, organized in foci within the hepatic lobule and surrounded with oval cells (Fig. 3B). Some of these clusters were also positive for $\beta$-galactosidase by immunohistochemistry (Fig. 3C). Such large foci of $\beta$-galactosidase-positive hepatocytes indicated that mature hepatocytes had divided during the course of the 2 -AAF regimen. The mean number of $\beta$-galactosidase-positive foci was $3.6 \pm 3.2$ (mean $\pm \mathrm{SD}$ ) per $\mathrm{cm}^{2}$ of examined liver sections. As expected, we never observed $\beta$-galactosidase-positive oval cells. We also observed isolated $\beta$-galactosidase-positive hepatocytes that were sometimes completely surrounded with oval cells (Fig. 3D), suggesting that not all hepatocytes had divided.

To evaluate the state of differentiation of hepatocytes, we assessed the presence of gamma-glutamyl transpeptidase (GGT) and of the placental form of glutathione-S-transferase (GSTp) using immunohistochemistry. Clusters of GGT- and GSTp-positive hepatocytes were detected as early as 6 weeks after the beginning of 2-AAF treatment. The cluster size varied amongst experimental animals. The mean number of GSTp-positive clusters recorded in more than $8 \mathrm{~cm}^{2}$ of liver sections in the experimental animals was $12.6 \pm$ 10.1 per $\mathrm{cm}^{2}$ of examined liver sections.

We analyzed the expression of $\beta$-galactosidase as well as GGT and GSTp in serial sections of the same foci. In most cases we found foci of GGT- and GSTp-positive hepatocytes that were negative for $\beta$-galactosidase. However we also detected foci of hepatocytes that were positive for $\beta$-galactosidase (Fig. 4A) as well as GSTp (Fig. 4B) and GGT (Fig. 4C). This clearly indicated that mature hepatocytes were able to give rise to preneoplastic foci. We determined that $3.9 \%$ of the GSTp-positive cluster was also positive for $\beta$-galactosidase. This proportion is lower than the proportion of initially labeled hepatocytes (25\%; Fig. 3A). Finally $80 \%$ of $\beta$-galactosidase-positive hepatocyte clusters were negative for GSTp and GGT, suggesting that proliferation of mature normal hepatocytes also occurred.

\section{Discussion}

In this study we analyzed cell lineage during a modified Solt-Farber regimen using in vivo retroviralmediated gene transfer. We demonstrated that proliferating oval cells could be transduced with high-titer recombinant retroviral vectors delivered via the biliary tract but not via a peripheral vein. However, concomitant labeling of proliferating hepatocytes did not allow us to study the fate of a specific cell population. In contrast, genetic labeling of mature hepatocytes before administration of 2-AAF clearly demonstrated that mature hepatocytes were able to dedifferentiate and re-express GSTp and GGT. This demonstrates that preneoplastic foci may arise from mature hepatocytes.

During the past years, many studies have addressed the lineage relationship between oval cells and liver tumors during the course of carcinogenic regimens. However, although evidence for a lineage relationship between oval cells and mature hepatocytes as well as biliary cells has been provided, the actual role of oval cells in the development of liver tumors still remains obscure. Previous studies suggested that oval cell proliferation and development of hepatocellular tumors occur independently and result from activation of different cell lineages (Anilkumar et al, 1995; Steinberg et al, 1991; Tarsetti et al, 1993). To document this hypothesis, we studied cell lineage using genetic labeling of cells in a modified SoltFarber regimen. Previously, the use of tritiated thymidine as a marker to follow the fate of labeled oval cells yielded contradictory results (Evarts et al, 1987; Gerlyng et al, 1994). Moreover, reutilization of the marker

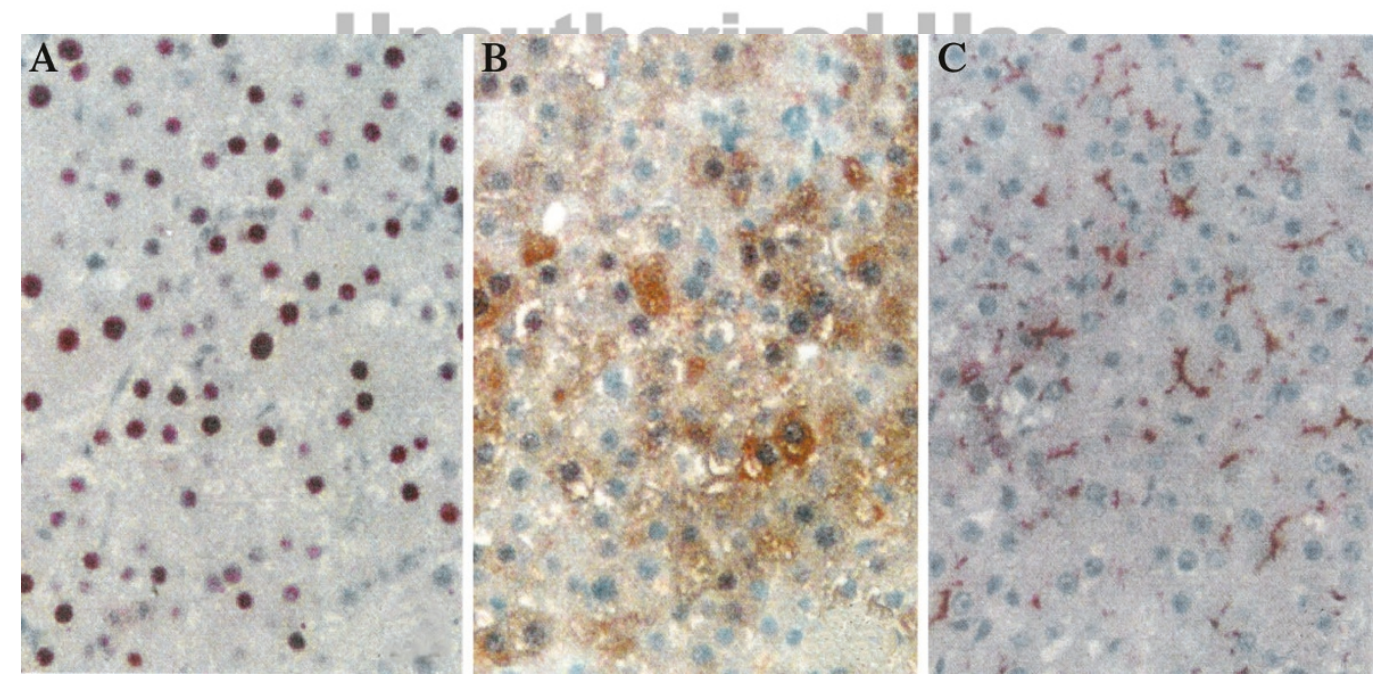

Figure 4.

Immunohistochemical detection of $\beta$-galactosidase and preneoplastic markers in prelabeled rats. Serial sections of the liver obtained in a prelabeled rat at the end of carcinogen administration showing a $\beta$-galactosidase-positive cluster (A), also positive for the placental form of glutathione-S-transferase (B) and gamma-glutamyl transpeptidase $(C)$. Hematoxylin counterstained. (Magnification, $\times 400$ ). 
after cell death may occur when using tritiated thymidine (Heiniger et al, 1971). Stable genetic labeling is a powerful tool to study cell lineage, and we reasoned that retroviral vectors, which are able to integrate the marker gene in the infected cell's genome, might achieve such a goal. Indeed we previously studied the fate of normal hepatocytes in long-term studies using this strategy (Bralet et al, 1994). However, in a previous attempt to study cell lineage in two carcinogenic models, we failed to infect oval cells with retroviral vectors administered via the portal vein (Bralet et al, 1996; Kitten and Ferry, 1998).

In the present study we report the successful transfer and expression of a marker gene to oval cells during the course of 2-AAF administration. $\beta$-galactosidase-positive oval cells were present only when high-titer retroviral solution was administered via the common bile duct. However, despite the infusion of retrovirus solution containing viral titers between $5 \times$ $10^{7}$ and $5 \times 10^{8}$ focus forming units $/ \mathrm{ml}$, we did not observe a high number of $\beta$-galactosidase-positive oval cells. Such low infectivity of oval cells and the absence of labeled oval cells when retroviral vectors were delivered intravenously may be related to the presence of a basal membrane, which is known to impair infection of cells with recombinant viral vectors (Huard et al, 1996). In addition, we were unable to specifically label oval cells, and we always concomitantly labeled hepatocytes together with oval cells after bile duct delivery of the vectors. Hepatocyte mitosis was present at the time of injection, and this may explain the presence of labeled hepatocytes in our conditions. Indeed, biliary delivery of retroviral vectors was found to be very effective to transduce regenerating hepatocytes in a receent study (De Godoy et al, 1999). This also demonstrated that, as previously observed, 2-AAF is not able to completely block hepatocyte division (Laws et al, 1952). Therefore labeled hepatocytes present 2 weeks after retroviral injection might be derived either from labeled hepatocytes or from labeled oval cells that are known to be able to differentiate into hepatocytes (Coleman et al, 1993; Evarts et al, 1987). It was therefore not possible to specifically follow the fate of a particular cell type in the liver using this labeling strategy.

To circumvent this drawback, we performed hepatocyte prelabeling before administration of 2-AAF. To this end retroviral vectors were injected at the peak of hepatocyte division after a two-thirds hepatectomy. Oval cells are not involved in this regenerative process, which results in specific labeling of mature hepatocytes. Injection of a single dose of cyclophosphamide was also performed to decrease immune responses against $\beta$-galactosidase-positive cells as previously demonstrated (Jooss et al, 1996). After recovery from hepatectomy, animals harboring prelabeled hepatocytes were treated with 2-AAF. We previously used this prelabeling strategy to analyze the effect of galactosamine on mature hepatocytes and to demonstrate that mature hepatocytes were able to re-express GGT after galactosamine administration (Kitten and Ferry, 1998).
Our present results demonstrated that preneoplastic foci can arise from differentiated hepatocytes. Indeed we observed hepatocyte foci that were positive for $\beta$-galactosidase as well as GSTp and GGT. In the normal rat liver, GGT expression is restricted to bile duct cells, and there is no expression of GSTp. These two enzymes are commonly used markers of preneoplastic liver lesions and reveal dedifferentiation of hepatocytes (Tatematsu et al, 1985). Because only mature hepatocytes expressed $\beta$-galactosidase before administration of 2-AAF, the presence of $\beta$-galactosidase-positive hepatocytes that also expressed GGT and GSTp after 2-AAF administration could only be explained by dedifferentiation of mature cells. If all foci were derived from mature hepatocytes, we should observe the same proportion of foci expressing $\beta$-galactosidase as that of hepatocytes expressing $\beta$-galactosidase before 2-AAF administration. Therefore, because the proportion of labeled hepatocytes before administration of $2-\mathrm{AAF}$ was $25 \%$, we expected that up to $25 \%$ of GSTp clones would express $\beta$-galactosidase. In contrast, we observed that the majority of GSTp foci were negative for $\beta$-galactosidase, and only $4 \%$ of GSTp foci were $\beta$-galactosidase positive. Many factors may explain this discrepancy: (a) The immune response could have eliminated $\beta$-galactosidase clones; (b) $\beta$-galactosidase expression may be switched off in some clones after inactivation of the promoter after cell division, as has been demonstrated in other tissues (Chen et al, 1997); (c) Finally, we cannot exclude the possibility that oval cells may contribute to the generation of some preneoplastic foci either directly or by differentiation of oval cells in hepatocytes that will subsequently dedifferentiate and give rise to foci. Obviously those preneoplastic foci deriving from oval cells would not be prelabeled and express $\beta$-galactosidase. Nevertheless, on a qualitative basis, our results are consistent with the existence of a direct lineage between mature hepatocytes and preneoplastic foci. Therefore, our data agree with the hypothesis proposed by Farber (1984) that dedifferentiation of mature hepatocytes occurs during carcinogen administration.

Whether mature hepatocytes are directly involved in tumor appearance could not be answered in the present study. Indeed, remodeling of nodules resulting in hepatocyte redifferentiation has long been described (Tatematsu et al, 1983). According to this hypothesis, we found here that most of the $\beta$-galactosidase-positive foci were negative for GSTp. We had observed similar $\beta$-galactosidase foci of apparently normal hepatocytes in a previous study (Bralet et al, 1996). This suggests that either normal mature hepatocytes divide during exposure to 2-AAF or that most preneoplastic foci arising from hepatocytes can remodel. Long-term studies are therefore needed to better clarify this issue and document the contribution of redifferentiation or remodeling to carcinogenesis.

Finally, we observed that $\beta$-galactosidase-positive hepatocytes may be completely surrounded with oval cells. This also demonstrated that prelabeled hepatocytes may survive as single cells and that proliferation of oval cells may surround preexisting hepatocytes and exclude them from the lobule. Therefore no lin- 
eage relationship should be deduced from the contact between hepatocytes and oval cells. In conclusion, our present findings demonstrate the presence of a direct lineage between hepatocytes and preneoplastic foci in a modified Solt-Farber regimen and support the view that the dedifferentiation hypothesis of liver cancer is still viable.

\section{Materials and Methods}

\section{Animals and Surgical Procedures}

Adult male Fischer rats, weighing 160 to 180 gm, were used in this study. The rats were maintained under a 12-hour light/dark illumination cycle and received food and drinking water ad libitum throughout the experimental period. 2-AAF was incorporated into their normal diet at $0.02 \%(\mathrm{w} / \mathrm{w})$. All surgical procedures were conducted on deeply anesthetized animals according to the guidelines of the French Ministry of Agriculture. Anesthesia was based on the use of ketamine $(50 \mathrm{mg} / \mathrm{kg}$ ) combined with pentobarbital (15 $\mathrm{mg} / \mathrm{kg}$ ). Two-thirds hepatectomies were performed according to the procedure of Higgins and Anderson (1931).

Liver biopsy specimens were obtained from the right lateral lobe after laparotomy. Each biopsy specimen was cut into two fragments. One was snapfrozen in dry ice-cold isopentane for cryostat sectioning and $\beta$-galactosidase staining. The other was immersed in formalin and paraffin embedded for routine histology and immunohistochemistry.

Rats were killed by injection of a lethal dose of pentobarbital. The livers were washed in situ by perfusion of PBS through the portal vein. After washing, fixation was obtained by perfusion with a $4 \%$ paraformaldehyde solution prepared in PBS. The livers were removed and cut into 5-mm thick blocks. Some tissue blocks were either snap-frozen in dry ice-cold isopentane for cryostat sectioning or immediately processed for $\beta$-galactosidase staining of whole fragment. The other blocks were immersed in formalin and paraffin embedded for immunohistochemistry.

\section{Cell Culture and Virus Preparation}

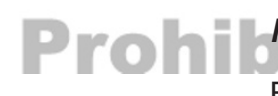

We used amphotropic recombinant retroviral vectors containing the $E$. coli $\beta$-galactosidase gene coupled to the nuclear localizing signal from an SV 40 large $T$ antigen (nls-lacZ gene) and produced by the TELCeB6 AF7-producing cell line (Cosset et al, 1995). Cells were cultured at $37^{\circ} \mathrm{C}$ in DMEM containing $10 \%$ fetal calf serum, $100 \mathrm{U} / \mathrm{ml}$ penicillin, and $100 \mathrm{mg} / \mathrm{ml}$ streptomycin. Once the cells reached confluence, the medium was harvested every day and filtered through a $0.45-\mu \mathrm{m}$ filter. The medium was used after concentration via tangential ultra filtration to achieve a higher titer as previously described (Kitten et al, 1997).

The retroviral titer was determined by infection of Te 671 cells in 6 -well dishes with $1 \mathrm{ml}$ of serial dilutions of the retrovirus-containing supernatant. The cells were stained 48 hours later with X-Gal, and the titer was defined as the number of $\beta$-galactosidase-positive foci multiplied by the dilution factor. After concentration the titer of the viral stocks routinely reached $5 \times$ $10^{7}$ to $5 \times 10^{8}$ focus forming units $/ \mathrm{ml}$.

\section{In Vivo Genetic Cell Labeling}

Animals were divided in two groups (Fig. 1). In Group 1 , genetic labeling was performed after the introduction of 2-AAF to target proliferating cells, mainly oval cells, induced by such regimen. In Group 2, genetic labeling was performed after a two-thirds hepatectomy performed 1 week before introduction of 2-AAF to target dividing hepatocytes.

In Group 1 (direct labeling), 2-AAF feeding was started at Day 0, 7 days before a two-thirds hepatectomy. Analysis of proliferating cells revealed that the peak of oval cell division occurred at Day 7 after partial hepatectomy. Therefore, because retroviral vectors are only able to infect dividing cells (Hajihosseini et al, 1993; Roe et al, 1993), 7 days after two-thirds hepatectomy (ie, at Day 14), the solution containing the retrovirus $(1 \mathrm{ml})$ was administered either intravenously (in the dorsal vein of the penis) or into the common bile duct to label preferentially oval cells. Rats were killed 1 or to 2 weeks later.

In Group 2 (prelabeled group), a two-thirds hepatectomy was performed 1 week before 2-AAF administration. Recombinant retroviruses $(1 \mathrm{ml})$ were injected twice intravenously (in the dorsal vein of the penis) at 22 and 27 hours after the hepatectomy. To circumvent rapid immune elimination of $\beta$-galactosidase-expressing cells, cyclophosphamide (100 $\mathrm{mg} / \mathrm{kg}$ body weight) was injected intravenously immediately before virus administration. At Day 7 after virus injection (ie, after completion of liver regeneration), the 2-AAF regimen was started and rats were killed 5, 6, or 10 weeks later.

\section{Histology}

Routine histology was performed on formalin-fixed/ paraffin-embedded sections.

\section{Histochemical X-Gal Staining}

Beta-galactosidase activity was assessed on 10- $\mu \mathrm{m}$ cryostat sections. Sections were incubated for 6 hours at $32^{\circ} \mathrm{C}$ in PBS containing $0.4 \mathrm{mg} / \mathrm{ml} \mathrm{X-Gal,} 4 \mathrm{~mm}$ potassium ferricyanide, $4 \mathrm{~mm}$ potassium ferrocyanide, and $2 \mathrm{~mm} \mathrm{MgCl}_{2}$. Sections were subsequently counterstained with hematoxylin and eosin.

\section{Immunohistochemistry}

Formalin-fixed/paraffin-embedded sections (5 $\mu \mathrm{m})$ were deparaffinized, and endogenous peroxidase activity was blocked by incubation for 30 minutes in a $3 \% \mathrm{H}_{2} \mathrm{O}_{2}$ solution in PBS. Diluted primary antibodies were applied either overnight at $4^{\circ} \mathrm{C}$ (diluted 1:1000 for the $\beta$-galactosidase antibody) or for 2 hours at room temperature (diluted 1:150 for GGT; diluted 1:20 for GSTp). Dilutions were performed in PBS containing bovine serum albumin (2\% w/v) and Tween $20(0.1 \%$ 
v/v). Positive cells were revealed with biotinylated anti-mouse and anti-rabbit immunoglobulin and streptavidin-peroxidase complex using amino-ethyl carbazole as a chromogenic substrate. Slides were counterstained with hematoxylin, and the number and size of the positive clusters were recorded optically at $\times 10$ magnification.

\section{Acknowledgements}

The authors thank Dr. Yannick Laperche for the gift of GGT antibodies.

\section{References}

Anilkumar TV, Golding M, Edwards RJ, Lalani EN, Sarraf CE, and Alison MR (1995). The resistant hepatocyte model of carcinogenesis in the rat: The apparent independent development of oval cell proliferation and early nodules. Carcinogenesis 16:845-853.

Bennoun M, Rissel M, Engelhardt N, Guillouzo A, Briand P, and Weberbenarous A (1993). Oval cell proliferation in early stages of hepatocarcinogenesis in simian virus 40 large $T$ transgenic mice. Am J Pathol 143:1326-1336.

Bralet MP, Branchereau S, Brechot C, and Ferry N (1994). Cell lineage study in the liver using retroviral mediated gene transfer: Evidence against the streaming of hepatocytes in normal liver. Am J Pathol 144:896-905.

Bralet MP, Calise D, Brechot C, and Ferry N (1996). In vivo cell lineage analysis during chemical hepatocarcinogenesis using retroviral-mediated gene transfer. Lab Invest 74:871881 .

Chen WY, Bailey EC, McCune SL, Dong JY, and Townes TM (1997). Reactivation of silenced, virally transduced genes by inhibitors of histone deacetylase. Proc Natl Acad Sci USA 94:5798-5803.

Coleman WB, Wennerberg AE, Smith GJ, and Grisham JW (1993). Regulation of the differentiation of diploid and some aneuploid rat liver epithelial (stem-like) cells by the hepatic microenvironment. Am J Pathol 142:1373-1382.

Cosset FL, Takeuchi Y, Battini JL, Weiss RA, and Collins MKL (1995). High-titer packaging cells producing recombinant retroviruses resistant to human serum. J Virol 69:74307436.

Dabeva MD, Hwang SG, Vasa SR, Hurston E, Novikoff PM, Hixson DC, Gupta S, and Shafritz DA (1997). Differentiation of pancreatic epithelial progenitor cells into hepatocytes following transplantation into rat liver. Proc Natl Acad Sci USA 94:7356-7361.

De Godoy JL, Malafosse R, Fabre M, Mehtali M, Houssin D, and Soubrane O (1999). In vivo hepatocyte retrovirusmediated gene transfer through the rat biliary tract. Hum Gene Ther 10:249-257.

Dempo K, Chisaka N, Yoshida Y, Kaneko A, and Onoé T (1975). Immunofluorescent study on alpha-fetoproteinproducing cells in the early stage of $3^{\prime}$-methyl-4dimethylaminoazobenzene carcinogenesis. Cancer Res 35: 1282-1287.

Dunsford H, Maset R, Salman J, and Sell S (1985). Connection of ductlike structures induced by a chemical hepatocarcinogen to portal bile ducts in the rat liver detected by injection of bile ducts with a pigmented barium gelatin medium. Am J Pathol 118:218-224.

Dunsford H and Sell S (1989). Production of monoclonal antibodies to preneoplastic liver cell populations induced by chemical carcinogens in rats and to transplantable morris hepatomas. Cancer Res 49:4887-4893.

Evarts RP, Nagy P, Marsden E, and Thorgeirsson SS (1987). A precursor-product relationship exists between oval cells and hepatocytes in rat liver. Carcinogenesis 8:1737-1740.

Fabrikant $\mathrm{JI}$ (1968). The kinetics of cellular proliferation in regenerating liver. J Cell Biol 36:551-565.

Farber E (1956). Similarities in the sequence of early histological changes induced in the liver of the rat by ethionine, 2-acetylaminofluorene and 3'-methyl-4-dimethylaminoazobenzene. Cancer Res 16:142-148.

Farber $E$ (1984). The multistep nature of cancer development. Cancer Res 44:4217-4223.

Farber E and Sarma D (1987). Hepatocarcinogenesis: A dynamic cellular perspective. Lab Invest 56:4-23.

Gerlyng P, Grotmol T, Stokke T, Erikstein B, and Seglen PO (1994). Flow cytometric investigation of a possible precursorproduct relationship between oval cells and parenchymal cells in the rat liver. Carcinogenesis 15:53-59.

Golding M, Sarraf CE, Lalani EN, Anilkumar TV, Edwards RJ, Nagy P, Thorgeirsson SS, and Alison MR (1995). Oval cell differentiation into hepatocytes in the acetylaminofluorenetreated regenerating rat liver. Hepatology 22:1243-1253.

Grisham JW (1962). A morphologic study of deoxyribonucleic acid synthesis and cell proliferation in regenerating rat liver: Autoradiography with thymidine- ${ }^{3} \mathrm{H}$. Cancer Res 22:842849 .

Grisham JW and Hartroft WS (1961). Morphologic identification by electron microscopy of "oval" cells in experimental hepatic degeneration. Lab Invest 10:318-333.

Grisham JW and Porta EA (1964). Origin and fate of proliferating hepatic ductal cells in the rat: Electron microscopic and autoradiographic studies. Exp Mol Pathol 2:317-332.

Hajihosseini M, lavachev L, and Price J (1993). Evidence that retroviruses integrate into post-replication host DNA. EMBO J 12:4969-4974.

Heiniger HJ, Friedrich G, Feinendegen E, and Cantelmo F (1971). Reutilization of 5-iodo-2'-deoxyuridine and ${ }^{3} \mathrm{H}$ thymidine in regenerating rat liver of mice. Proc Soc Exp Biol Med 137:1381.

Higgins GM and Anderson RM (1931). Experimental pathology of the liver. I. Restoration of the liver of the white rat following partial surgical removal. Arch Pathol 12:186-202.

Hixson DC, Faris RA and Thompson NL (1990). An antigenic portrait of the liver during carcinogenesis. Pathobiology 58: 65-77.

Huard J, Feero WG, Watkins SC, Hoffman EP, Rosenblatt DJ, and Glorioso JC (1996). The basal lamina is a physical barrier to herpes simplex virus-mediated gene delivery to mature muscle fibers. J Virol 70:8117-8123.

Izembart A, Aguado E, Gauthier O, Aubert D, Moullier P, and Ferry N (1999). In vivo retrovirus-mediated gene transfer to the liver of dogs results in transient expression and induction of a cytotoxic immune response. Hum Gene Ther 10:29172925. 
Jooss K, Yang Y, and Wilson JM (1996). Cyclophosphamide diminishes inflammation and prolongs transgene expression following delivery of adenoviral vectors to mouse liver and lung. Hum Gene Ther 7:1555-1566.

Kalderon D, Roberts BL, Richardson WD, and Smith $A E$ (1984). A short amino acid sequence able to specify nuclear location. Cell 39:499-509.

Kitten O, Cosset FL, and Ferry N (1997). Highly efficient retrovirus-mediated gene transfer into rat hepatocytes in vivo. Hum Gene Ther 8:1491-1494.

Kitten $O$ and Ferry N (1998). Mature hepatocytes actively divide and express gamma-glutamyl transpeptidase after D-galactosamine liver injury. Liver 18:398-404.

Laws JO, Mabille P, Royer R, and Rudali G (1952). Etude histo-pathologique des lésions provoquées par le 2-acétylaminofluorène dans différents organes du rat. Bull Assoc Franç et Cancer 39:450-460.

Lemischka IH (1993). Retroviral lineage studies: Some principals and applications. Curr Opin Gen Dev 3:115-118.

Lenzi R, Liu M, Tarsetti F, Slott P, Alpini G, Zhai W, Paronetto F, Lenzen R, and Tavoloni N (1992). Histogenesis of bile duct-like cells proliferating during ethionine hepatocarcinogenesis. Lab Invest 66:390-402.

Novikoff PM, Ikeda T, Hixson DC, and Yam A (1991). Characterizations of and interactions between bile ductule cells and hepatocytes in early stages of rat hepatocarcinogenesis induced by ethionine. Am J Pathol 139:1351-1368.

Petersen BE, Bowen WC, Patrene KD, Mars WM, Sullivan AK, Murase N, Boggs SS, Greenberger JS, and Goff JP (1999). Bone marrow as a potential source of hepatic oval cells. Science 284:1168-1170.

Petersen BE, Zajac VF, and Michalopoulos GK (1997). Bile ductular damage induced by methylene dianiline inhibits oval cell activation. Am J Pathol 151:905-909.

Petropoulos CJ, Yaswen P, Panzica M, and Fausto N (1985). Cell lineages in liver carcinogenesis: Possible clues from studies of the distribution of alpha-fetoprotein RNA sequences in cell populations isolated from normal, regenerating and preneoplastic rat livers. Cancer Res 45:5762-5768.

Roe TY, Reynolds TC, Yu G, and Brown P (1993). Integration of murine leukemia virus DNA depends on mitosis. EMBO $\mathrm{J}$ 12:2099-2108.

Sarraf C, Lalani E, Golding M, Anilkumar TV, Poulsom R, and Alison M (1994). Cell behavior in the acetylaminofluorenetreated regenerating rat liver. Am J Pathol 145:1114-1126.
Schirmacher P, Held W, Yang D, Biempica L, and Rogler C (1991). Selective amplification of periportal transitional cells precedes formation of hepatocellular carcinoma in SV 40 large Tag transgenic mice. Am J Pathol 139:231-241.

Sell S (1978). Distribution of alpha fetoprotein- and albumincontaining cells in the livers of Fischer rats fed four cycles of N2-fluorenylacetamide. Cancer Res 38:3107-3113.

Sell S and Dunsford H (1989). Evidence for the stem cell origin of hepatocellular carcinoma and cholangiocarcinoma. Am J Pathol 134:1347-1363.

Sell S and Salman J (1984). Light and electron microscopic autoradiographic analysis of proliferating cells during the early stages of chemical hepatocarcinogenesis in the rat induced by feeding N-2-fluorenylacetamide in a cholinedeficient diet. Am J Pathol 114:287-300.

Solt $D$ and Farber $E$ (1976). New principle for the analysis of chemical carcinogenesis. Nature 263:701-703.

Steinberg P, Hacker HJ, Dienes HP, Oesch F, and Bannasch P (1991). Enzyme histochemical and immunohistochemical characterization of oval and parenchymal cells proliferating in livers of rats fed a choline-deficient/DL-ethioninesupplemented diet. Carcinogenesis 12:225-231.

Tarsetti F, Lenzi R, Salvi R, Schuler E, Rijhsinghani K, Lenzen R, and Tavoloni N (1993). Liver carcinogenesis associated with feeding of ethionine in a choline-free diet: Evidence against a role of oval cells in the emergence of hepatocellular carcinoma. Hepatology 18:596-603.

Tatematsu M, Ho R, Kaku T, Ekem J, and Farber E (1984). Studies on the proliferation and fate of oval cells in the liver of rats treated with 2-acetylaminofluroren and partial hepatectomy. Am J Pathol 114:418-430.

Tatematsu M, Mera Y, Ito N, Satoh K, and Sato K (1985). Relative merits of immunohistochemical demonstrations of placental, A, B and C forms of glutathione S-transferase and histochemical demonstration of gamma-glutamyl transferase as markers of altered foci during liver carcinogenesis in rats. Carcinogenesis 6:1621-1626.

Tatematsu M, Nagamine Y, and Farber E (1983). Redifferentiation as a basis for remodeling of carcinogen-induced hepatocyte nodules to normal appearing liver. Cancer Res 43:5049-5058.

Thompson-Hayner N, Braun L, Yaswen P, Brooks M, and Fausto $N$ (1984). Isozyme profile of oval cells, parenchymal cells, and biliary cells isolated by centrifugal elutriation from normal and preneoplastic livers. Cancer Res 44:332-338. 